\title{
THE GROUPING OF VILLAGES ON KB SUPPORTING INDICATORS AS A BASIC MAPPING FOR FORMATION KAMPUNG KB IN SURABAYA
}

\author{
Erma Oktania Permatasari ${ }^{1}$, Wahyu Wibowo ${ }^{2}$, Budi Priyono ${ }^{3}$ \\ 1,2 Statistics, Institut Teknologi Sepuluh Nopember, Surabaya 60111, Indonesia \\ 3 Universitas Hang Tuah, Surabaya 60111, Indonesia \\ e-mail: erma.oktania@gmail.com
}

\begin{abstract}
Population problems in Indonesia is still important and complex issues that must be resolved. Indonesia has the fourth largest population after China, India and the United States. Uncontrolled population growth will cause problems, such as lack of employment opportunity, unemployment and increased crime. To solve these problems, the government through BKKBN (The National Population and Family Planning) increase the promotion of Family Planning (KB) with the slogan "two children are enough". To support the success of KB program, the government is introducing Kampung KB program. Based on description, this research will be investigated how the grouping of villages based on KB supporting indicators as basic mapping for formation Kampung KB in Surabaya, because Surabaya is the second largest city in Indonesia after Jakarta. The variables used in this research are contraceptive prevalence rate/ CPR, the survival rate of contraceptive use, mix contraceptive, unmet need, the number of pra prosperous and prosperous I familyies, the number of toddler, the number of elderly, long-term contraceptionon method, the number of male participation KB, the number of women of childbearing age, the number of patriarch by employment status, the number of patriarch by education level, the number of population, and the number of teenagers marriages under 20 years old. The results show that using cluster hierarchy analysis and cluster non hierarchy analysis, the optimum grouping is 4 groups.
\end{abstract}

Keywords: Population, KB program, Kampung KB.

\section{INTRODUCTION}

Population problems in Indonesia is still important and complex issues that must be resolved. Indonesia has the fourth largest population after China, India and the United States. Based on the results of population census in 2010, in ten years since 2000, Indonesia's population increased to 32.5 million, with an average population growth rate is $1.49 \%$ each year, as many as 237.5 million people in 2010.This value is estimated to be 271.1 million people in 2020 and 305.6 million people in 2035. Indonesia is one of country whose rate of population growth quickly. Uncontrolled population increase will cause many problems, such as unemployment, increased crime, urbanization, etc. High population growth will hamper the rate of development in various areas, therefore efforts to control the population must be done.

Based on the population problems, the government has taken some restriction, i.e. the restriction of baby born, children allowance for government employees, age of marriage, etc. Government through the BKKBN (National
Population and Family Planning) starts to introduce family planning (KB) programs since the 60's with the slogan "two children are enough". To support the success of the KB program, the government is trying to promote Kampung KB program. Head of center BKKBN, Dr. Surya Chandra explains that Kampung KB is one of the mental revolution program based family to build the character of Indonesian nation [1]. With the Kampung KB program, the benefits of $\mathrm{KB}$ program can be perceived for many peoples. There are several indicators or criteria which used to determine whether an area is eligible as Kampung KB or not. Some of this criteria are the number of families who belong to pra prosperous and prosperous I category, contraceptive prevalence rate of less than $50 \%$, low of long-term contraception method, high of unmet need, low of the number of male participation $\mathrm{KB}$, the number of toddler at least 20 toddlers, the number of elderly at least 20 elderly, the number of teenagers marriages under 20 years old, low of school enrollment rates, and high of unemployment.

Based on the description, so in this paper, will be investigated how the grouping of 
villages based on $\mathrm{KB}$ supporting indicators as a basic mapping for formation Kampung $K B$ in Surabaya, remember Surabaya is the second largest city in Indonesia after Jakarta.

\section{LITERATURE REVIEW}

2.1 Basic of Family Planning (KB) Program in the National Development

Family planning $(\mathrm{KB})$ is an effort to increase awareness and public participation through:

a. Maturing age of marriage,

b. Birth control,

c. Fostering family resilience,

d. Improving the prosperous of family to make a small family, happy, and prosperous.

The basis of establishment family planning (KB)in national development, that is Law No.10 / 1992 on Development of Population and Family Prosperous and International Agreements (MDGs), which states that:

"All couples and individuals have the basic right to decide freely and responsibly the number, spacing and timing of their children and have the information and means to do so, and the right to obtain the highest standard of sexual and reproductive health".

\subsection{Definition and Terms of Family Planning (KB)}

There are several definitions and terms in family planning (KB), there are:

a. Reproductive age, which is the age of average woman is able to give birth, in 15-49 years.

b. Reproductive couple / PUS, which is couples where his wife at the age of 15-49 years old was able to give birth.

c. Family Planning, which is an attempt to regulate the number, spacing and timing of birth in order to achieve the purpose of family reproduction.

d. Ever use of contraception, which is the status of couples who ever use contraception but they are not currently using contraception at the time of data collection.

e. Current use of contraception, which is the status of couples who are using contraception at the time of data collection. f. Contraceptive choice, which is contraception that is being used by PUS.

g. Contraceptive switching, which is a process that PUS has change contraception that previously used by the others contraception.

h. Unmet need, which is the percentage of woman of childbearing age who do not want to have children anymore, or want to postpone the next birth, but do not wearing contraception.

\subsection{Contraception}

Contraception that can be used are:

a. Modern

Modern grouped into:

1) Have a hormonal, which are pills, implants and injections

2) Non hormonal, which are AKDR or spiral (IUD), condoms, diaphragms, male sterilization (vasectomy) and woman sterilization (tubal ligation)

b. Natural

Natural:

1) Periodic abstinence

2) Lactationalamaleorhea /LAM

3) Withdrawl

\section{c. Traditional}

Traditional:

Herbal drugs and potions

\section{$2.4 \quad$ Cluster Analysis}

Cluster analysis is a method to classify the objects of observation into several groups in order to obtain a group where the objects in one group have the same characteristics, while with the other member group have different characteristics [3]. There are two procedures of clustering, which are hierarchical clustering and non-hierarchical clustering.

In hierarchy procedure, the formation of cluster is done by cutting dendrogram that resulting from analysis. The formation of cluster is determined by search the distance between two objects that will be combined into one. The distance that used in this research is squared Euclidean distance. The formula of squared Euclidean distance is.

$$
d^{2}(x, y)=\sum_{j=1}^{p}\left(x_{j}-y_{j}\right)^{2}
$$

In hierarchy procedure has some methods to clustering, one of them is ward method. If $A B$ is a cluster that get from combination between groups $A$ and $B$, then the 
sum of distance in cluster for all the items from the average of vector cluster is.

$$
\begin{aligned}
S S E_{A} & =\sum_{i=1}^{n_{A}}\left(y_{i}-\bar{y}_{A}\right)^{\prime}\left(y_{i}-\bar{y}_{A}\right) \\
S S E_{B} & =\sum_{i=1}^{n_{B}}\left(y_{i}-\bar{y}_{B}\right)^{\prime}\left(y_{i}-\bar{y}_{B}\right) \\
S S E_{A B} & =\sum_{i=1}^{n_{A B}}\left(y_{i}-\bar{y}_{A B}\right)^{\prime}\left(y_{i}-\bar{y}_{A B}\right)
\end{aligned}
$$

Whereas $\bar{y}_{A B}=\left(n_{A} \bar{y}_{A}+n_{B} \bar{y}_{B}\right) /\left(n_{A}+n_{B}\right)$ and $n_{A}, n_{B}$ and $n_{A B}=n_{A}+n_{B}$ is the number of points $A, B$, and $A B$. Ward method performed by combining two clusters, which are $A$ and $B$ to minimize increasing of SSE which can be formulated as follows.

\subsection{Criteria Elbow}

Criteria elbow is a method to determine the number of clusters by looking at the percentage of variance explained. The percentage of variance explained is the ratio between variance from the cluster to the total variance. Basically, to select a number of clusters was performed by adding the other clusters so that there is sufficient information can be used to continue the next process.

\section{RESEARCH METHODOLOGY}

\subsection{Data Source}

The data that used in this research is secondary data that obtained from Badan Pemberdayaan Masyarakat dan Keluarga Berencana (Bapemas dan KB) in Surabaya at 2014.Unit samples in this research are reproductive couple (PUS) in each village in Surabaya.

\subsection{Variable Data and Research \\ Variables that used in this research} consisted of several variables $(\mathrm{X})$ which are.

Table 1. Research Variable

\begin{tabular}{cl}
\hline Variable & \multicolumn{1}{c}{ Explanation } \\
\hline$X_{1}$ & Contraceptive prevalence rate/ CPR \\
$X_{2}$ & The Survival Rate of Contraceptive Use \\
$X_{3}$ & Mix Contraceptive \\
$X_{4}$ & Unmet Need \\
$X_{5}$ & The Number of Pra Prosperous and Prosperous I Families \\
$X_{6}$ & The Number of Toddler \\
$X_{7}$ & The Number of Elderly \\
$X_{8}$ & Long-term Contraception Method \\
$X_{9}$ & The Number of Male Participation KB \\
$X_{10}$ & The Number of Women of Childbearing Age (15-49 years) \\
$X_{11}$ & The Number of patriarchs by employment status \\
$X_{12}$ & The Number of patriarchs by education level \\
$X_{13}$ & The Number of populations \\
$X_{14}$ & The Number of teenagers marriages under 20 years old \\
\hline
\end{tabular}

Definition of Operational Variable:

a. Contraceptive Prevalence Rate/CPR

Contraceptive Prevalence Rate is the percentage of PUS that is using contraception.

$$
C P R=\frac{\text { PUS that using contraception }}{\text { The number of PUS }} \times 100
$$

b. The Survival Rate of Contraceptive Use 
The Survival Rate of Contraceptive Use is the proportion of contraception that still use specific contraception after period or actively family planning $(\mathrm{KB})$ participants. c. Mix Contraceptive is the number PUS that use specific contraception at 100 couples of reproductive couple(PUS).

$$
\text { Percantage of PUS that use specific contraception }=\frac{\text { The number of PUS that use KBk }}{\text { The number of PUS that use KB }} x 100
$$

d. Unmet Need is a woman who does not want to have children, but they are not using contraception.

Unmet Need $=$ The number of PUS that does not include to participants KB reduced by the number of PUS who want to have children really soon and the number of pregnant.

e. The Number of Pra Prosperous and Family Prosperous $I$ is the result of phasing family prosperous group to the Family PreProsperous and Family Prosperous I

f. The Number of toddlers is the number of toddlers in each village

g. The Number of elderlies is the number of elderlies in each village

h. Long-term contraception method is the use of contraceptives types of IUD, implant, MOW, MOP

i. The Number of male participation KB is the number of males who use contraceptives MOP and condoms

j. $\quad$ The Number of women of childbearing age is the number of women of childbearing age, is $15-49$ years so it is possible to have a large percentage of birth

k. The Number of patriarchs by employment status is the number of heads of family who works and does not work

I. The number of patriarchs by education level is the number of heads of family who did not finish primary level of education (SD), graduated from elementary (SD)-junior high school (SMP), graduated from high school (SLTA) and graduated from the Academy / University

$\mathrm{m}$. The population is the number of populations in each village

$\mathrm{n}$. The number of teenagers marriages under 20 years old is the number of teenagers who marriages under the age of 20 years

\subsection{Method of Analysis Data}

There are steps to analysis in this research

a. Collecting the data that used in this research from Badan Pemberdayaan Masyarakat dan Keluarga Berencana (Bapemas dan KB) in Surabaya.

b. Study literature by literature books, journals, tasks and field observations.

c. Making description about characteristics of reproductive couple (PUS) in Surabaya.

d. Forming a grouping of villages in Surabaya based on indicators to support family planning (KB) by cluster analysis

e. Mapping the formation of village in Surabaya.

\section{RESULT AND ANALYSIS}

\subsection{Characteristics of Indicators Supporting KB \\ The following is a descriptive characteristic of some indicators supporting KB.}

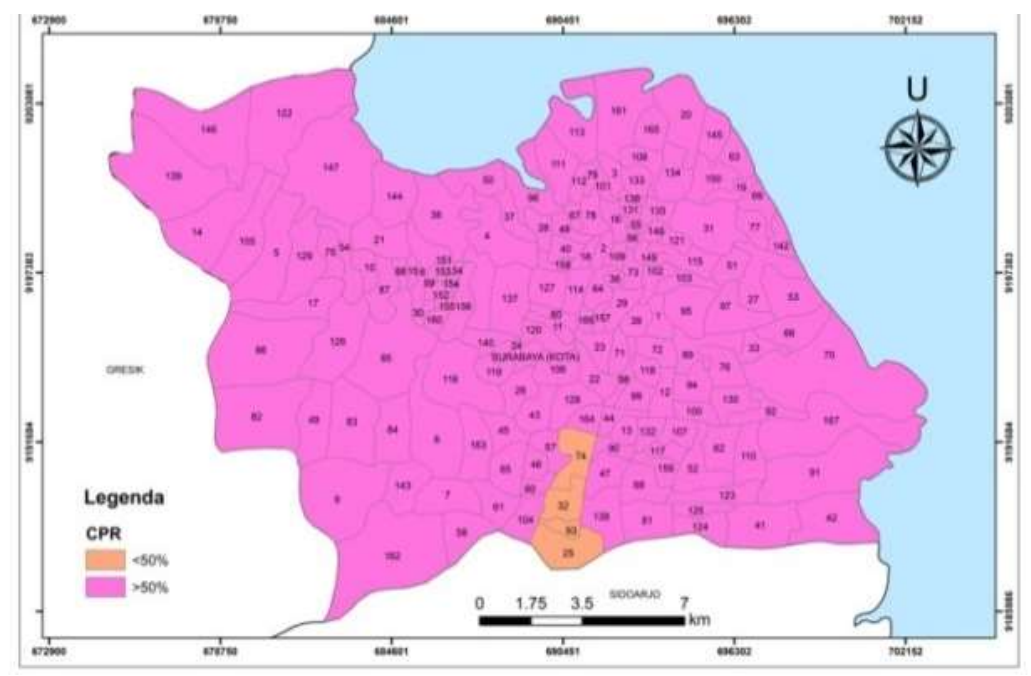

Figure 1. Distribution Map of CPR 
Contraceptive Prevalence Rateis the percentage of couples of childbearing age who was use contraception.Information about the number of CPR is very helpful to set a policy to control population, as well as the family planning (KB) services in the form of preparing for contraception services such as sterilization, using IUD, the preparation of contraception and drugs, also counseling services to accommodate the needs and respond the complaints of contraception user. Figure1 is a map of the distribution CPR in Surabaya that divided into two groups, first is the village with CPR values $<50 \%$ and the village with CPR values $>50 \%$. Based on Figure1. it can be seen that a village with CPR value $<50 \%$ is Dukuh Menanggal village, Gayungan, Ketintang, and Menanggal. A village with the lowest CPR value is Ketintang village, while the village with the highest value of CPR is Kertajaya village.

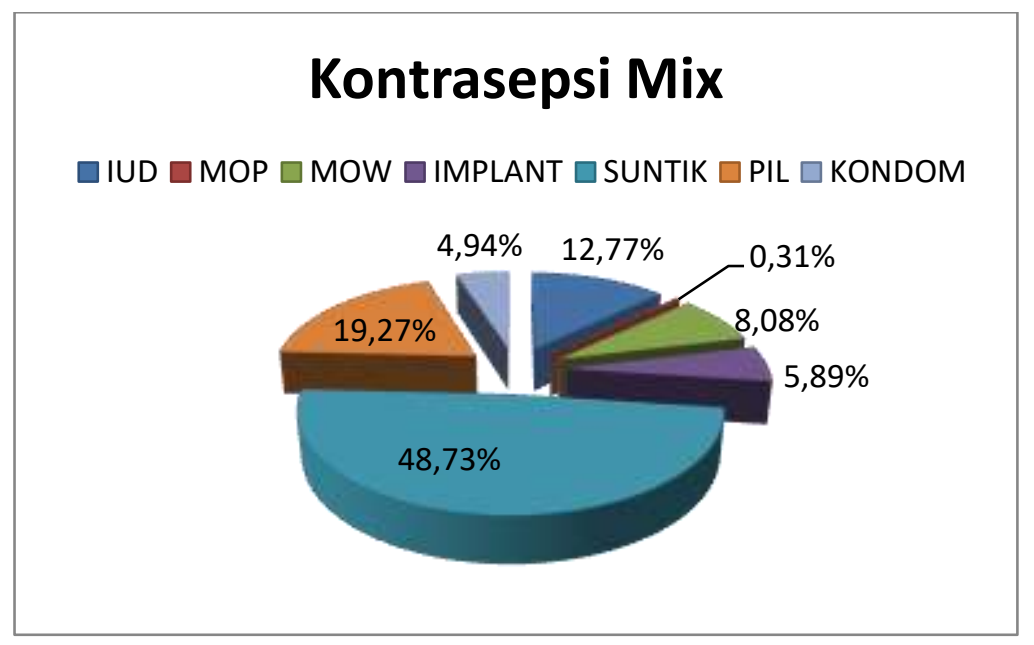

Figure 2..Percentage Contraceptives Mix

Contraceptive mix is the number of couples of childbearing age who use specific contraceptionat 100 couples of reproductive couple.Contraception that used such as IUD, MOP, MOW, implants, injections, pills and condoms. Contraception using injections is the largest usefulwith a percentage of $48.73 \%$ from the population in Surabaya, while contraception using MOP is the smallest usefulwith a percentage of $0.31 \%$ in Surabaya.

\subsection{Grouping Village Based Supporting Indicators KB}

Grouping villages in Surabaya based on indicators that supporting family planning (KB) can be done by using hierarchical cluster analysis or non-hierarchical cluster analysis.

\section{a. Grouping Using Hierarchical Cluster Analysis}

Grouping using hierarchical cluster analysis using four methods, which are the method of single linkage, complete linkage, average linkage and ward linkage. Single linkage method is a method for grouping two objects that have the shortest distance at the first. Complete linkage method is a method for grouping two objects that have the furthest distance at the first. Average linkage method is a method for grouping objects based on the average distance that obtained by doing the average of all the distances between the objects at the first time. Ward linkage method is a method for grouping objects based on the distance between the two clusters from the total sum of square two clusters in each variable. Based on the 4 methods, the results are getting the different of grouping, to determine which the best method, it can be done by looking at the value icdrate (Internal Cluster Dispersion Rate) of each method.

Table 2. The Value of Icdrate Each Method

\begin{tabular}{cccr}
\hline & \multicolumn{3}{c}{ Method } \\
\hline $\begin{array}{c}\text { Single } \\
\text { Linkage }\end{array}$ & $\begin{array}{c}\text { Complete } \\
\text { Linkage }\end{array}$ & $\begin{array}{l}\text { Average } \\
\text { Linkage }\end{array}$ & Ward Linkage \\
\hline 0.717376 & 0.32618 & 0.425875 & 0.318483 \\
\hline
\end{tabular}


Table 2. shows that the minimum value of icdrate is in the ward linkage method with the value is 0.318483 . So, to grouping villages based on indicators supporting family planning $(\mathrm{KB})$, the best method is ward linkage method.
In determining the optimum number of groups, can use Pseudo $F$ method. The value of Pseudo $F$ on the best method is from ward linkage method as follows.

Table 3. The Value of Pseudo F Ward LinkageMethod

\begin{tabular}{cc}
\hline $\begin{array}{c}\text { Number of } \\
\text { Groups }\end{array}$ & $\begin{array}{c}\text { Score } \\
\text { Pseudo F }\end{array}$ \\
\hline 3 & 6.1599787 \\
4 & 6.872486 \\
5 & 5.8978446 \\
6 & 5.135732 \\
\hline
\end{tabular}

Table 3. shows the value of Pseudo FStatistic from ward linkage method so that can be known the optimal number of groups with the best grouping method that already known to use icdrate value analysis. It is known that the maximum value of Pseudo $F$ is equal to 6.872486 withnumber of groups as many as 4 groups. Results of grouping by ward method can be seen in Table 4.

Table 4. Grouping Village Using Ward Linkage

\section{Groups}

Airlangga, Alon-AlonContong, BalasKlumprik, Balongsari, Bangkringan, Banjarsugihan, Baratajaya, BendulMerisi, Benowo, Bongkaran, Bringin, Bubutan, Bulak, Dr.Soetomo, DukuhKupang, DukuhMenanggal, Dukuh Pakis, DukuhSutorejo, EmbongKaliasin, Gayungan, GebangPutih, Genteng, Genting, Greges, GunungAnyar, GunungAnyarTambak, Gunungsari, Jajar Tunggal, Jambangan, Jemurwonosari, Jeruk, Kalianak, Kalijudan, Kalisari, Kapasari, Karah, Karangpilang, Karangpoh, Kebonsari, KedungBaruk, KedungCowek, KejawanPutih, Kemayoran, Kendangsari, Kenjeran, Keputih, Keputran, Kertajaya, Ketabang, Ketintang, KlampisNgasem, Krembangan Utara,

Group 1 Krembangan Selatan, Kutisari, Lakasantri, LidahKulon, LidahWetan, Made, ManukanWetan, ManyarSebrangan, Margorejo, MedokanAyu, MedokanSemampir, Menanggal, Menur, Mulyorejo, NgindenJangkungan, Nyamplungan, Pagesangan, Pakal, PanjangJiwo, Peneleh, Penjaringan Sari, Perak Barat, Perak Utara, PradahDkk, Pucangsewu, PutatGede, Romokalisari, RungkutKidul, Samikerep, Semolowaru, Sidosermo, Siwalankerto, Sonokwijenan, SukoliloBaru, Sukomanunggal, SumberRejo, SumurWelut, TambakWedi, Tandes, Tanjungsari, TambakLangon, TambakOsowilangun, Tegalsari, TenggilisMejoyo, Warungunung

Ampel, Asemrowo, BabatJerawat, Babatan, Bulak Banteng, DukuhSetro, Dupak, Gundih, Jepara, Kandangan, Kapasan, Kebraon, Kedungdoro, Kedurus,

Group 2 Lontar, ManukanKulon, Perak Timur, RungkutMenanggal, Rungkut Tengah, Sememi, Sidodadi, Simokerto, Simolawang, SimomulyoBaru, Tambak Sari, Tambakrejo, TembokDukuh, Wiyung

Gading, Kalirungkut, KapasMadya, Mojo, Moro Krembangan, PacarKeling,

Group 3 PacarKembang, Pegirian, Ploso, Rangkah, Sidotopo, SidotopoWetan, Tanah Kali Kedinding, Ujung, Wonokusumo, Wonorejo 
Banyu Urip, Darmo, Jagir, Klakahrejo, KomplekKenjeran, KupangKrajan,

Group 4 Ngagel, NgagelRejo, Pakis, Petemon, Prapen, Putat Jaya, Sawahan, Sawunggaling, TambakDono, Wonokromo

Based on the grouping in Table 4, shows that some of the villages which has some similarities characteristics will form one group, and each group is formed have different characteristics with other groups with a map of grouping is shown in Figure 3.

Figure 3. Grouping Village Using Hierarchy Method

Figure 4. shows that based on the variables unmet need, the number of pra prosperous and prosperous I families, the number of toddler, the number of women of childbearing age and the number of population, the group that has the highest value is the third group and the group that has the lowest value is the first group. Thus, members of third group are villages that have priority to the establishment of kampung KB.

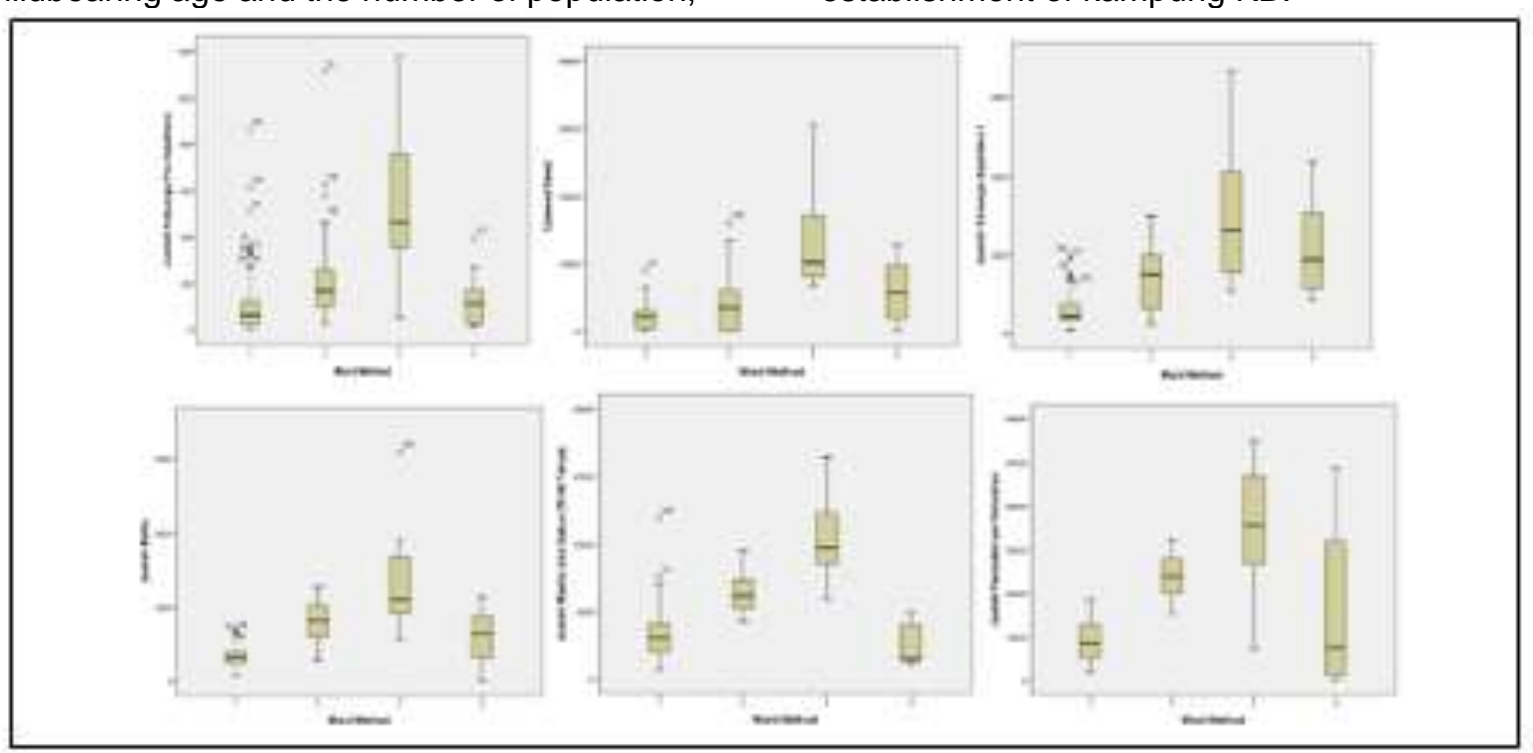

Figure 4. Characteristics of Grouping Based on unmet need, the number of pra prosperous and prosperous I families, the number of toddler, the number of women of childbearing age and the number of population.

\section{b. Grouping Using Cluster Analysis} Non-Hierarchy

There are various methods for classifying objects using non-hierarchical cluster analysis, one of its method is $\mathrm{K}$ Means.K-Means Cluster Analysis used if it requires a certain number of clusters. To determine the maximum number of clusters that 
will be used on the K-Means clustering analysis, that is using the coefficients in the Agglomeration Schedulein the ward linkage method, which can be illustrated in the following scree diagram.

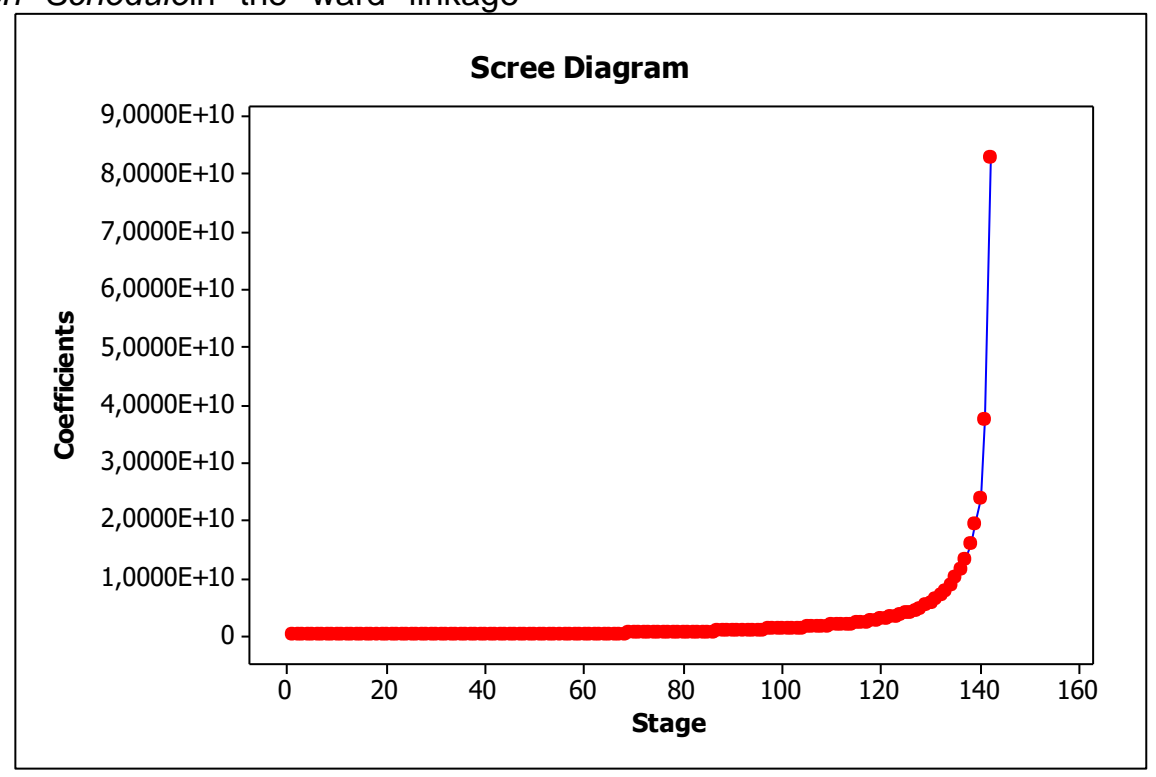

Figure 5.Scree Diagram

Based on the results of scree diagram in Figure 5 , it can be seen that the first spike is happening between stage 140 to stage 141 . So, a maximum number of clusters $(142+1)$ - (141$1)+1=4$ clusters. So that, the number of clusters to be used in the K-Means clustering analysis as much as 4 clusters. Based on the analysis of K-Means, members of each cluster are as follows.

Table 5. Grouping Village Using K-Means

\section{Member of Group}

Airlangga, Ampel, Asemrowo, BabatJerawat, Babatan, Bulak Banteng, DukuhSetro, Dupak, Gundih, Jajar Tunggal, Jepara, Kalirungkut, Kandangan, Kapasan, Kebraon, KedungBaruk, Kedungdoro, Kedurus,

Group 1 Kendangsari, Kertajaya, KlampisNgasem, Kutisari, Lontar, ManukanKulon, MedokanAyu, Perak Timur, Rangkah, RungkutKidul, RungkutMenanggal, Rungkut Tengah, Sememi, Semolowaru, Sidodadi, Simokerto, Simolawang, SimomulyoBaru, Tambak Sari, Tambakrejo, TembokDukuh, Wiyung

Alon - AlonContong, BalasKlumprik, Balongsari, Bangkingan, Banjarsugihan, Baratajaya, BendulMerisi, Benowo, Bongkaran, Bringin, Bubutan, Bulak, Dr.Soetomo, DukuhKupang, Dukuh, Menanggal, Dukuh Pakis, DukuhSutorejo, Ketintang, Krembangan Utara, Krembangan Selatan, Lakarsantri ， LidahKulon, LidahWetan, Made, ManukanWetan, ManyarSabrangan, Margorejo,

Group 2 MedokanSemampir, Menanggal, Menur, Mulyorejo, NgindenJangkungan, Nyamplungan, Pagesangan, EmbKaliasin, Gayungan, GebangPutih, Genteng, Genting, Greges, Gubeng, GunungAnyar, GunungAnyarTambak, Gunungsari, Jambangan, Jemurwonosari, Jeruk, Kalianak, Kalijudan, Kalisari, Kapasari, Karah, Karangpilang, Karangpoh, Kebonsari, KedungCowek, KejawanPutih, Kemayoran, Kenjeran, Keputih, Keputran, Ketabang, Pakal, PanjangJiwo, Peneleh, Penjaringan Sari, Perak Barat, Perak Utara, 
PradahDkk, Pucangsewu, PutatGede, Romokalisari, Samikerep, Sidosermo, Simomulyo, Siwalankerto, Sonokwijenan, SukoliloBaru, Sukomanunggal, SumberRejo, SumurWelut, TambakWedi, Tandes, Tanjungsari, Tb Langon, Tb Osowilangun, Tegalsari, TenggilisMejoyo, Warugunung

Gading, KapasMadya, Mojo, Moro Krembangan, PacarKeling,

Group 3 PacarKembang, Pegirian, Ploso, Sidotopo, SidotopoWetan, Tanah KK, Ujung, Wonokusumo, Wonorejo

Banyu Urip, Darmo, Jagir, Klakahrejo, KompKenjeran, KupangKrajan,

Group 4 Ngagel, NgagelRejo, Pakis, Petemon, Prapen, Putat Jaya, Sawahan, Sawunggaling, TambakDono, Wonokromo

Based on clustering using K-Means in Table 5. it can be seen that several villages which has some similarities characteristics and form to be one group with the grouping map can be seen in Figure 6 as follows.

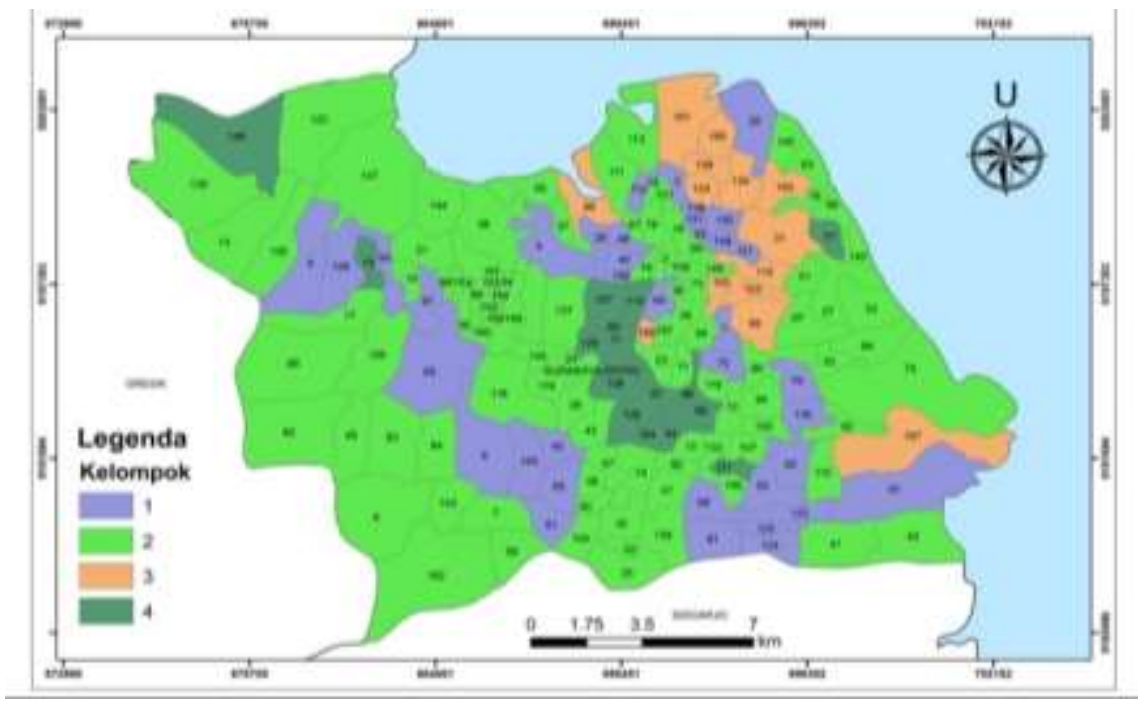

Figure 6. Map Clustering Using K-Means

Figure 7. shows that based on the variables unmet need, the number of prosperous I families, and the number of unemployment patriarch, the group that has the highest value is the third group and the group that has the lowest value is the second group.
Thus, members of third group are villages that have priority to the establishment of kampung $\mathrm{KB}$.

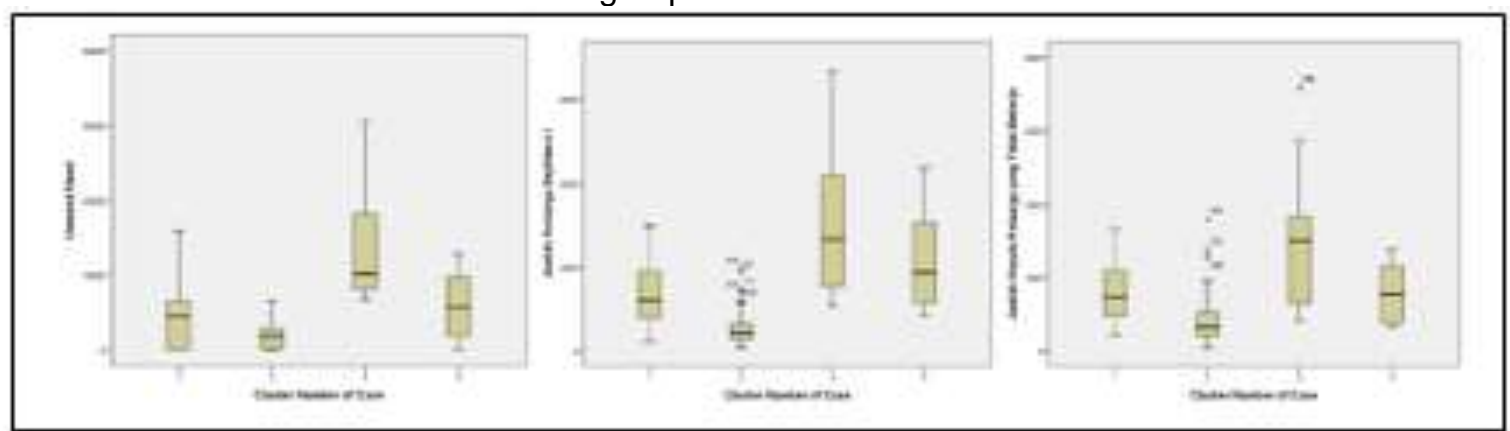

Figure 7. Characteristics of Grouping Based on unmet need, the number of prosperous I families, and the number of unemployment patriarch 


\section{c. Comparative Analysis of Cluster Hierarchy and Non Hierarchy \\ The result of grouping using} hierarchical cluster analysis based on the best method which use is ward linkage with a maximum group as many as 4 clusters.
Selection of the best methods use lcdrate analysis and determination of the maximum group using analysis of Pseudo $F$. The result from non-hierarchical cluster analysis using KMeans with a maximum group as many as 4 clusters using the Elbow method.

Table 6. Icdrate Analysis Between Ward Linkage and K-Means

\begin{tabular}{ccc}
\hline \multirow{2}{*}{ Number of groups } & \multicolumn{2}{c}{ Methode } \\
\cline { 2 - 3 } & Ward Linkage & K-Means \\
\hline 4 & 0.404420206 & 0.390992887
\end{tabular}

Table 6. shows that both methods have too little or not too far in difference value of icdrate, but the minimum icdratein K-Means method amounted of 0.390992887.So that, to classify villages based on indicators supporting family planning $(\mathrm{KB})$, the best method to used is K-Means.

\section{CONCLUSIONS}

Based on the analysis and discussion, it can be concluded that the grouping of villages in Surabaya based on indicators supporting KB, using analysis of cluster hierarchy (with the best method is ward linkage) and non-hierarchy (KMeans method) are obtainedthat optimum grouping is four groups, with members in each third group are villages that have priority to the establishment of the Kampung KB. Based on the icdrate value also found that the best method in this researchis K-Means method.

\section{ACKNOWLEDGEMENT}

The authors greatly acknowledge the support from Institut Teknologi Sepuluh Nopember and Universitas Hang Tuah Surabaya Indonesia for providing the necessary resources to carry out this research work. The authors are also grateful to Institut Teknologi Sepuluh Nopember and Universitas Hang Tuah, Surabaya, Indonesia who always give me opportunity to improve my research. And the last the authors would like to say thank to the anonymous reviewers and journal editorial board for their many insightful comments, which have significantly improved this article.

\section{REFERENCES}

Gorunescu, F. 2011. Data Mining: Concepts, Models, and Techniques. Berlin: Springer Science \& Business Media.
Hair, J. F., Black, W. C., Babin, B. J., \& Anderson, R. E. (2010). Multivariate Data Analysis. Seventh Edition. New Jersey: Prentice Hall.

Johnson, R. A., \& Winchern, D. W. (2007). Applied Multivariate Data Analysis Sixth Edition.New Jersey: Prentice Hall.

Mantra, I. B. 1985. DemografiUmum. Yogyakarta: PustakaPelajar.

Tarmizi T. 2016. BKKBN: Kampung KB butuh revolusi mental [Online]. Available:http://www.antaranews.com/ berita/553896/bkkbn-kampung-kbbutuh-revolusi-mental. 